\title{
The Effectiveness of Sicenting Application Towards Knowledge and Attitude of Responding Stunting Regency in Singaparna District, Tasikmalaya District in 2019
}

\author{
$1^{\text {st }}$ Sinta Fitriani \\ Stikes Respati Tasikmalaya \\ Tasikmalaya, Indonesia \\ *taniesa1571@gmail.com
}

\author{
$2^{\text {nd }}$ Hariyani Sulistyoningsih \\ Stikes Respati Tasikmalaya \\ Tasikmalaya, Indonesia
}

\begin{abstract}
Background: To increase the capacity of cadres in early detection and prevention of stunting through the provision of health information, health promotion media are needed that can assist cadres in carrying out these activities. The Centing Application (Detection and Prevent Stunting) is a software for early detection of stunting events in toddlers as well as an Android-based stunting information media which is carried out by entering toddlers' data in the form of age, sex, weight and height. Objective: This is to determine the effectiveness of the Centing Application to the Knowledge and Attitudes of Posyandu Cadres in Singaparna District in 2019. Method: The type of research used is quantitative analytic design method Quasi Experiment One Group Pretest-Posttest approach. The population is 24 cadres of stunting response. The sampling technique is purposive sampling with the following criteria: willing to be a respondent, bring a smartphone. Instruments used: questionnaire and $\mathrm{Si}$ centing application. Results: there is the influence of the critical application in increasing the knowledge of stunting response cadres with a $t$ value of 19.080> 2.068. While the attitude variable has a value asymp.sig $(2$ tailed $)=0,000<0.05$ meaning that there is a difference between the value of the cadre's attitude before and after means that there is a positive influence on changes in the attitude of the cadre stunting response.
\end{abstract}

Keywords-Sicenting Application, Knowledge, Attitude, Stunting

\section{INTRODUCTION}

Stunting is defined as a short or very short body state based on the Body Length index by Age (PB / U) or Body Height by Age (TB / U) with a threshold (z-score) between -3 SD up to <-2 elementary school. Stunting in children is a long-term result of chronic consumption of a low-quality diet combined with morbidity, infectious diseases and environmental problems [1].

The incidence of stunting (short) under five is a major nutritional problem facing Indonesia. Based on Nutrition Status Monitoring data for the past three years, short has the highest prevalence compared to other nutritional problems such as malnutrition, thinness, and fat. The prevalence of short toddlers has increased from 2016 which is $27.5 \%$ to $29.6 \%$ in 2017 . The prevalence of short toddlers in Indonesia tends to be static. The results of the Basic Health Research (Riskesdas) in 2007 showed the prevalence of short toddlers in Indonesia at $36.8 \%$. In 2010 , there was a slight decline to $35.6 \%$. However, the prevalence of short toddlers increased again in 2013 to $37.2 \%[2]$

West Java Province in 2017 had a stunting prevalence of $29.2 \%$ [3]. Based on data from the Tasikmalaya District Health Office it was found that the Singapore District District was one of the areas with stunting prevalence in February 2019 of 136 infants with very short nutritional status and 444 infants with short status [4].

Impacts that can arise from stunting can be divided into short-term and long-term impacts. Short-term impacts include an increase in morbidity and mortality; Cognitive, motor and verbal development in children is not optimal; and increasing health costs. Long-term Impacts That arise: Posture that is not optimal when mature (shorter than in general); Increased risk of obesity and other diseases; Decreased reproductive health; Less than optimal learning capacity and performance during school term; and Nonoptimal work productivity and capacity [5].

One of the efforts to detect and prevent stunting can be done at posyandu. Monitoring the growth of children under five in the posyandu is a very strategic effort to detect early growth disorders. Early prevention is one of the best ways to reduce the prevalence of stunting in West Java. The most important procedures for early prevention are routine screening and persistent follow-up for toddlers. The Posyandu program made by the government has been very good and has become a concrete solution to reach all levels of society. The better the service provided by the posyandu is proportional to the improvement in the 
quality of public health. The routine screening process for height / age should be a mandatory agenda in every activity carried out at the posyandu [6].

To increase the capacity of cadres in early detection and prevention of stunting through the provision of health information, health promotion media are needed that can assist cadres in carrying out these activities. The Centing Application (Detection and Prevent Stunting) is a software for early detection of stunting events in toddlers as well as an Android-based stunting information media which is carried out by entering toddlers' data in the form of age, sex, weight and height. Determination of nutritional status will be processed quickly so that cadres can easily determine the nutritional status of the toddler. In addition Si Centing also provides a stunting information menu from the definition, causes, prevention and handling of stunting in the form of an attractive image so that it can be used as a media during counseling activities. Based on the background above, the author is interested in conducting research with the title "Effectiveness of the Centing Application to Knowledge and Attitudes of Stunting Response Cadres in Singapore District in 2019". The purpose of this study is to determine the Effectiveness of Centing Applications on Knowledge and Attitude of Stunting Response Cadres in Singapore District in Tahun 2019

\section{METHOD}

Type of research used is quantitative analytical method design Quasi Experiment One Group Pretest-Posttest approach. The population is 24 cadres of stunting response. The sampling technique is purposive sampling with the following criteria: willing to be a respondent, bring a smartphone. Instruments used: questionnaire and $\mathrm{Si}$ centing application. Analysis of research with test when normally distributed and Wilcoxon test for data that is not normally distributed.

\section{A. Characteristics of respondents}

\section{RESULTS}

TABLE I. CHARACTERISTICS OF STUNTING RESPONSE CADRES SINGAPARNA DISTRICT, TASIKMALAYA REGENCY IN 2019

\begin{tabular}{|c|c|c|c|}
\hline No & Characteristic & $\mathbf{F}$ & $\%$ \\
\hline 1 & $\begin{array}{l}\text { Cadre age } \\
\text { a. }<20 \text { years } \\
\text { b. } 20 \text { - } 35 \text { years old } \\
\text { c. } 36-50 \text { years } \\
\text { d. }>50 \text { years } \\
\text { amount }\end{array}$ & $\begin{array}{c}0 \\
7 \\
8 \\
9 \\
24\end{array}$ & $\begin{array}{c}0 \\
29,2 \\
33,3 \\
37,5 \\
100\end{array}$ \\
\hline 2 & $\begin{array}{l}\text { Education level } \\
\text { a. Graduated from elementary school } \\
\text { b. Graduated from junior high } \\
\text { c. Graduated from high school } \\
\text { d. End of PT } \\
\text { Amount }\end{array}$ & $\begin{array}{c}2 \\
\\
8 \\
11 \\
3 \\
24\end{array}$ & $\begin{array}{l}8,3 \\
33,3 \\
45,8 \\
12,5 \\
100\end{array}$ \\
\hline 3 & $\begin{array}{l}\text { Occupations } \\
\text { a. Work } \\
\text { b. Not working } \\
\text { Amount }\end{array}$ & $\begin{array}{c}6 \\
18 \\
24 \\
\end{array}$ & $\begin{array}{c}25 \\
75 \\
100 \\
\end{array}$ \\
\hline 4 & $\begin{array}{l}\text { Old to become Cadre } \\
\text { a. }<5 \text { years } \\
\text { b. } 5-10 \text { years } \\
\text { c. }>10 \text { years } \\
\text { amount }\end{array}$ & $\begin{array}{c}10 \\
6 \\
8 \\
24\end{array}$ & $\begin{array}{c}41,7 \\
25,0 \\
33,3 \\
100\end{array}$ \\
\hline
\end{tabular}

Based on the table above the characteristics of stunting response cadres are the majority aged $>50$ years $(37.5 \%)$, the majority of high school graduates are 11 people $(45.8 \%)$, the majority of cadres do not work are 18 people

$(75 \%)$ and the majority work became Posyandu cadres $<5$ years, 10 people $(41.7 \%)$.

$B$. Increased knowledge and attitudes of cadres

An increase in knowledge and attitudes of cadres with the following results:

TABLE II. KNOWLEDGE OF CADRES BEFORE AND AFTER USING THEAPPLICATION SI CENTING IN SINGAPARNA DISTRICT TASIKMALAYA REGENCY IN 2019

\begin{tabular}{|l|r|r|r|r|r|r|}
\hline & \multicolumn{1}{|c|}{ Mean } & \multicolumn{1}{|c|}{ N } & Std. Deviation & Std. Error Mean & P value & \multicolumn{1}{c|}{ T hitung } \\
\hline Knowledge before & 7.17 & 24 & 1.606 & .328 & 0,000 & 19,080 \\
\hline Knowledge after & 13.54 & 24 & .884 & .180 & & \\
\hline
\end{tabular}

Based on table II it is found that the average cadre knowledge value before being given the centing application is 7.17 with a standard deviation of 1,606. while the average cadre knowledge after being given the centing application is 13.54 with a standard deviation of 0.884 .

Statistical test results obtained p value 0,000 means that there is a significant difference between cadre knowledge before and after the centing application is given. So it can be concluded that there is an influence given the critical application in increasing knowledge of stunting response cadres with a $\mathrm{t}$ value of $19.080>$ from $\mathrm{t}$ table 2.068.

C. Attitude of cadres before and after using the application

As for the attitude of cadres responding to stunting before and after the application of the centing is listed in the following table: 
TABLE III. THE ATTITUDE OF CADRES BEFORE AND AFTER USING THE APPLICATION SI CENTING IN THE SINGAPARNA DISTRICT OF TASIKRNALAYA IN 2019

\begin{tabular}{|c|c|c|c|c|}
\hline & & $\mathbf{N}$ & Mean Rank & Sum of Ranks \\
\hline \multirow{4}{*}{ After attitude - before attitude } & Negative Ranks & $0^{\mathrm{a}}$ & .00 & .00 \\
\hline & Positive Ranks & $24^{\mathrm{b}}$ & 12.50 & 300.00 \\
\hline & Ties & $0^{\mathrm{c}}$ & & \\
\hline & Total & 24 & & \\
\hline & & & \multicolumn{2}{|c|}{$\begin{array}{c}\text { attitude } \\
\text { Before - after }\end{array}$} \\
\hline \multicolumn{3}{|l|}{$\bar{Z}$} & \multicolumn{2}{|r|}{$-4.333^{b}$} \\
\hline \multicolumn{3}{|l|}{ Asymp. Sig. (2-tailed) } & \multicolumn{2}{|r|}{.000} \\
\hline \multicolumn{5}{|l|}{ a. Wilcoxon Signed Ranks Test } \\
\hline \multicolumn{5}{|l|}{ b. Based on negative ranks. } \\
\hline
\end{tabular}

Based on table III above, it is found that negative ranks are 0 meaning that there is no decrease in the value of attitude before and after the centing application is given. While positive ranks are 24 , it means that all cadres experience an increase in the value of attitude before and after the centing application is given with a mean rank of 12.50 and a sum of rank of 300.00 . The ties value in the attitude variable is 0 meaning that there is no similar attitude value between before and after the centing application is given.

Based on the statistical test output, the value of asymp.sig ( 2 tailed) is $0,000<0.05$, which means that there is a significant difference between the cadre attitudes before and after using the Centing application, which means there is a significant and positive influence given by the centing application to changes stunting response cadre attitude.

\section{DISCUSSION}

The Si Centing application is an Android-based health innovation designed to facilitate cadres in early detection of stunting events and become a media for health promotion when conducting counseling and counseling. The use of this application can increase the knowledge and attitude of cadres, this is in accordance with the results of research which states that the use of cellular technology in research conducted by Otu A, Ebenso B, Okuzu $\mathrm{O}$ and Dawodu EO shows that mHealth innovations can help alleviate some health system constraints such as lack of equipment to collect data, and limited access to training in health such as maternal and child health, and reproductive health. mHealth improves health system functions and knowledge by $11 \%$ from before and changes in attitudes towards disease [7].

Of various forms of information and telecommunications technology, mobile phones are considered to be a very suitable tool to advance education in developing regions. The use of this smartphone is more effective than modules without applications [8]. This is consistent with the results of research conducted by Wahyuni $T$ regarding the effect of smartphone applications on a person's knowledge and skills in stimulating growth and development of infants, indicating an increase in knowledge and skills. Therefore, the provision of information through attractive media tools will facilitate a person to do the stimulation independently [9].
Media is a tool or material used as a tool to convey messages. The media functions to further clarify the messages that will be delivered by the message giver to the recipient of the message. The use of media is very important to explain the messages or material delivered during counseling. The use of extension media should not lead to a double understanding. The extension media used must meet media requirements. These requirements include interesting, in accordance with the goals of counseling, easily captured, brief, clear, in accordance with the messages to be conveyed, and polite [10].

Based on the results of the research above stated that android-based media has an influence in increasing knowledge. Android-based smartphone is a concrete manifestation of technological advances in the field of communication whose users around the world have reached 1.4 billion active users. Indonesia as one of the world's citizens has the effect of having an android smartphone with the number of android smartphone users in Indonesia has reached 47 million users. In the 2015 Hongko Pulung Seto study, where the android applicationbased learning media was able to increase the average value of EFI (Electronic Fuel Injection) learning material. That is allegedly because the android application-based learning media has mobile properties that can be used anywhere so that it is able to attract interest in learning. This has an impact on the effectiveness of the learning so that it can improve learning outcomes in the learning material.

Based on the results of the study it was found that the average cadre knowledge value before being given the centing application was 7.17 with a standard deviation of 1,606. while the average cadre knowledge after being given the centing application is 13.54 with a standard deviation of 0.884 . Statistical test results obtained $p$ value 0,000 means that there is a significant difference between cadre knowledge before and after the centing application is given. So it can be concluded that there is an influence given the critical application in increasing knowledge of stunting response cadres with a $t$ value of $19.080>$ from $t$ table 2.068.

Knowledge is the result of "knowing" and from this happens after a person senses a certain object. Sensing to an object occurs through the five human senses namely vision, hearing, smell, taste and touch with oneself. At the time of sensing to produce knowledge is strongly influenced by the intensity of the attention of the 
perception of the object. Most of human knowledge is obtained through the eyes and ears [11].

There are several factors that influence a person's knowledge and attitude. According to Notoadmojo explained that knowledge is influenced by the level of education, age, and experience. Education provides an influence on one's level of knowledge, with higher education will affect higher mastery of the material that must be mastered. Age gives an influence where age can affect the memory or memory possessed by someone. The older a person eats the process of mental development will get better. Thus, the more mature a person's level of development affects the person's way of gaining knowledge. Another thing is the ease of information, because information can help speed up someone to obtain new knowledge [11].

Applications The centing an android-based health innovations that are designed to facilitate early detection of cadres in the incidence of stunting and a media when carrying out health promotion and education counseling. The use of this application can increase the knowledge and attitudes of cadres, this is in accordance with the results of Handayani's research in 2019 in Garut Regency which states that there are significant differences between cadre knowledge before and after application application is free ofchildren stunting with $\mathrm{p}$ values $<0.001$. The results showed that the increase in cadre knowledge by $25.1 \%$. explained that the use ofapplications smartphonethe haspotential to be used as a means of health promotion that can improve one's knowledge and attitudes [3, 12].

To increase knowledge, innovative health promotion media is needed, one of which is a learning media based on Android application that has a mobile nature that can be used anywhere so that it is able to attract interest in receiving health information.

Based on the statistical test output obtained asymp.sig value ( 2 tailed) is $0,000<0.05$ meaning that there is a significant difference between cadre attitudes before and after using the Si Centing application, which means there is an influence significant and positive application is given by the centing to the changing attitudes of stunting cadres.

Attitude is a reaction or response that is still closed from someone to a stimulus or object. Attitude is not an action or activity but is a predisposition to the action of a behavior. That attitude is still a closed reaction, not an open reaction or open behavior. Attitude is a readiness to react to objects in a particular environment as an appreciation of the object $[11,13]$.

The results of this study are in accordance with the results of the study Handayani in 2019 in Garut Regency which states that there is a significant difference between knowledge before and after the application of stuntingfree children is given the test results it is known that the value of $p<0.001$ can thus be stated that a significant difference in attitude before and after the provision of information through the application offree children stunting-. The average\% increase in attitude before and after the provision of information through the application offree children stunting- $76.2 \%$.
Attitudes arise based on the evaluation process in individuals who give conclusions about the stimulus in the form of good value, negative, positive, pleasant not pleasant. The attitude structure consists of three mutually supporting components namely cognitive, affective, and conative components. The cognitive component is a representation that is believed by individuals to have an attitude, the affective component is a feeling that involves emotional aspects, and conative is an aspect of a certain tendency to behave in accordance with the attitudes of a person [14].

Cadre attitude is a reflection of cadres' perceptions of the tasks they carry, including early detection of development. The better the attitude of the cadres, the cadres have a positive perception of their duties in the early detection of developments so that the cadres can implement it well [15].

Android-based health promotion media make it easier for cadres to obtain information so as to increase positive perceptions within the cadre to be able to carry out their duties of early detection of stunting and disseminating health information about stunting prevention early on.

\section{CONCLUSIONS}

There are the influence of the application of the centing application in increasing knowledge and attitudes of stunting response cadres in Singaparna Sub-district Tasikmalaya Regency in 2019.

\section{SUGGESTIONS}

The Centing application can be used by cadres in carrying out their duties of early detection of stunting and making media health promotion when conducting counseling or counseling in Integrated Healthcare Center activities so thatcan be early cases of stuntingdetected in infants andcan be done preventionearly.

\section{ACKNOWLEDGMENTS}

We would like to thank the STIKES Respati, the Singaparna Public Health Center, the Cikunir Village Government and the stunting response cadres for their collaboration so that this research activity could be carried out in accordance with the targets set.

\section{REFERENCES}

[1] WHO, Nutrition Landscape Information System (NLIS) country profile indicators: interpretation guide. Switzerland, 2010.

[2] The Indonesian Ministry of Health, Basic Health Research in 2013. Jakarta: Indonesian Ministry of Health, 2014

[3] N. J. Handayani T, Tarawan V, "Increased Knowledge and Attitudes of Cadres About Stunting in Toddlers Age 12 - 36 Months Through Application of Free Stunting (AbsChildren)," J. Midwifery, vol. 5, no. 4, pp. 357-363.

[4] Tasikmalaya District Health, "Profile of Tasikmalaya District Health Office," Tasikmalaya.

[5] RI Ministry of Health, "Bulletin of the health data and information window," Jakarta, 2018

[6] A. Setyowati, M., \& Retno, "Mapping the Status of Toddler Nutrition in Supporting the Achievement of the Millennium Development Goals (MDGs)," Public Health, vol. 10, no. 2, pp. 10-21, 2015.

[7] D. E. Otu A, Ebenso B, Okuzu O, "Using a mHealth tutorial application to change the knowledge and attitude of frontline health workers to Ebola virus disease in Nigeria: a before and after study," Hum. Resour. Health, vol. 14, no. 5, 2016. 
[8] S. S. Barnett I, Befani B, "Designing an impact evaluation for a mobile phone application for nutrition service delivery in Indonesia," CDI Dev. Semin., 2014.

[9] Wahyuni T, "The Effect of Mother Cares Application on Increasing Parents' Knowledge and Skills in Stimulating Toddler Growth and Age 12-18 Months," Med. Cendikia, vol. 4, no. $1,2017$.

[10] S. I. Suiraoka I, Health Education Media. Graha knowledge. Yogyakarta, 2012.

[11] S. Notoatmodjo, Health Promotion; Teori anda Application. Jakarta: Rineka Copyrighted, 2012.
[12] S. S. Coughlin SS, Whitehead M, Sheats JQ, Mastromonico J, "A Review of Smartphone Applications for Promoting Physical Activity," Jacobs J. Community Med., 2016.

[13] Sinta Fitriani, Health Promotion. Yogyakarta: Graha Science, 2011.

[14] L. V. Adistie F, Maryam NNA, "Health Cadres Knowledge about Early Detection of Malnutrition in Toddlers.," J. Sci. Technol. Appl. Community, 2017.

[15] I. H. Pakasi AM, Korah BH, "Relationship of Health Cadres Knowledge and Attitudes with Posyandu Services," Midwife Sci. 